\title{
Archaeological Investigation of the San Juan Dam, 41BX266, Bexar County, Texas
}

David B. Hafernick

I. Waynne Cox

Anne A. Fox

Follow this and additional works at: https://scholarworks.sfasu.edu/ita

Part of the American Material Culture Commons, Archaeological Anthropology Commons, Environmental Studies Commons, Other American Studies Commons, Other Arts and Humanities Commons, Other History of Art, Architecture, and Archaeology Commons, and the United States History Commons

Tell us how this article helped you.

This Article is brought to you for free and open access by the Center for Regional Heritage Research at SFA ScholarWorks. It has been accepted for inclusion in Index of Texas Archaeology: Open Access Gray Literature from the Lone Star State by an authorized editor of SFA ScholarWorks. For more information, please contact cdsscholarworks@sfasu.edu. 
Archaeological Investigation of the San Juan Dam, 41BX266, Bexar County, Texas

Creative Commons License

(c) $)(1)$ (9)

This work is licensed under a Creative Commons Attribution-NonCommercial 4.0 International License 


\section{ARCHAEOLOGICAL INVESTIGATION OF THE SAN JUAN DAM, 41 BX 266, BEXAR COUNTY, TEXAS}

David B. Hafernik, I. Waynne Cox, and Anne A. Fox

Center for Archaeological Research

The University of Texas at San Antonio

Archaeological Survey Report, No. 179 





\section{ARCHAEOLOGICAL INVESTIGATION OF THE SAN JUAN DAM, $41 \mathrm{BX} 266$, BEXAR COUNTY, TEXAS}

David B. Hafernik, I. Waynne Cox, and Anne A. Fox

Center for Archaeological Research

The University of Texas at San Antonio ${ }^{\circledR}$

Archaeological Survey Report, No. 179 
The following information is provided in accordance with the General Rules of Practice and Procedure, Chapter 41.11 (Investigative Reports), Texas Antiquities Committee:

1. Type of investigation: archaeological testing;

2. Project name: San Juan Dam;

3. County: Bexar County, Texas;

4. Principal investigator: Jack D. Eaton; coprincipal investigator: Anne A. Fox;

5. Name and location of sponsoring agency: San Antonio River Authority;

6. Texas Antiquities Committee Permit No. 686;

7. Published by the Center for Archaeological Research, The University of Texas at San Antonio, 78285-0658, 1989.

A list of publications offered by the Center for Archaeological Research can be obtained by sending $\$ 1.00$ to the Center for Archaeological Research, The University of Texas at San Antonio, San Antonio, Texas 78285-0658. 


\begin{abstract}
On April 18, 1988, an archaeological crew from the Center for Archaeological Research at The University of Texas at San Antonio conducted a testing program at the historic dam for Mission San Juan Capistrano, San Antonio, Texas. The results of the excavations and the corresponding archival research are reported. Conclusions are drawn as to the dam's location, formation, and function.
\end{abstract}




\section{TABLE OF CONTENTS}

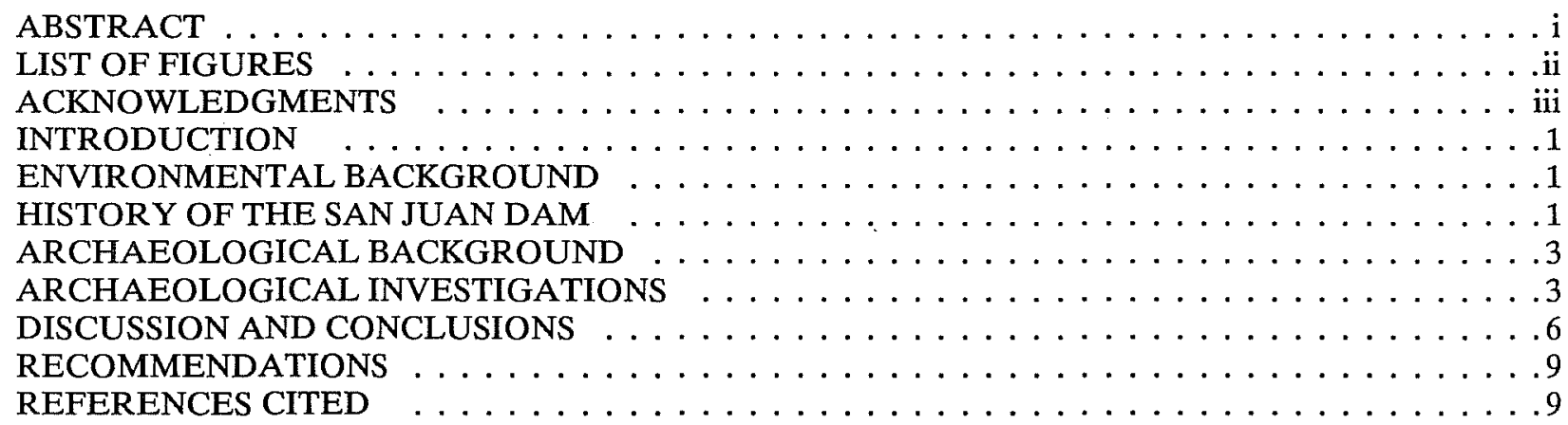

\section{LIST OF FIGURES}

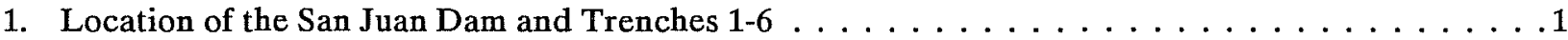

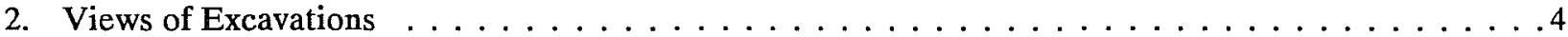

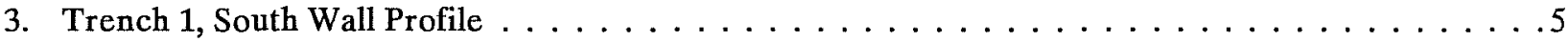

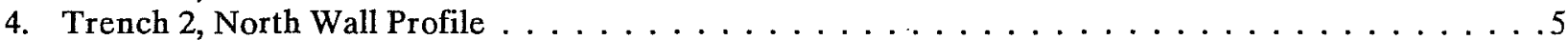

5. Trench 5 , South Wall Profile $\ldots \ldots \ldots \ldots \ldots \ldots$

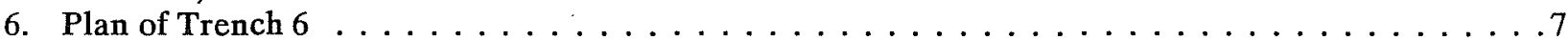

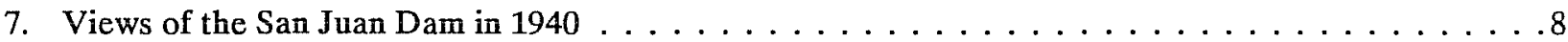




\section{ACKNOWLEDGMENTS}

We wish to thank David Schweers of the San Antonio River Authority for his help in locating pertinent maps and information on the dam and acequia. Dr. Geoffrey Blaney, assistant professor of engineering at The University of Texas at San Antonio, kindly offered his insights into the form and function of the dam. County archivist John Leal and the staff of the Daughters of the Republic of Texas Research Library provided help with the documentary research.

The crew included Anne A. Fox, David B. Hafernik, I. Waynne Cox, and Kenneth M. Brown, of the Center staff. Volunteers included Darla Cox, Tommy Tomesal, and Clint McKenzie. Illustrations for this report were drafted by Kenneth Brown (Fig. 1) and David Hafernik (Figs. 3-6). 



\section{INTRODUCTION}

In April 1988, personnel from the Center for Archaeological Research at The University of Texas at San Antonio conducted test excavations in an attempt to locate and document the dam associated with Mission San Juan Capistrano under contract with the San Antonio River Authority (SARA). The dam, constructed in the early 1730 s, diverted water from the San Antonio River into an acequia (ditch) to provide water for the irrigation of the mission fields.

The dam had not had water flowing over it since 1957, and had become covered with dirt and overgrown with vegetation. Prior to testing it was unsure if the dam was still intact, and if so, in what condition it might be found. Through testing we hoped to determine the exact location of the dam and the beginning point of the acequia with its corresponding headgate.

The project was conducted under the supervision of Jack Eaton, acting Center director. Anne A. Fox was the project director and field director. The work was done under Texas Antiquities Committee Permit No. 686.

\section{ENVIRONMENTAL BACKGROUND}

The San Juan dam is situated on an old channel of the San Antonio River above the eastern bank of the present channel opposite Mission San José (Fig. 1). The river was rechannelized, and much of the spoil was placed on the area west of the site to a depth of several feet. The area was at one time utilized as a city park but is currently abandoned.

Vegetation at the site consists of grasses, herbaceous plants, and shrubs. The old river channel is lined with large pecan, mesquite, and hackberry trees. Many of the pecan trees are large enough to have served as witness trees for deed record information.

\section{HISTORY OF THE SAN JUAN DAM}

Mission San Juan Capistrano was first established in 1716 in east Texas as Mission San José de las Nazonis. The mission was abandoned in 1719 because of French incursions into the area, but reestablished in 1721 (Webb 1952 Vol. II:556). In

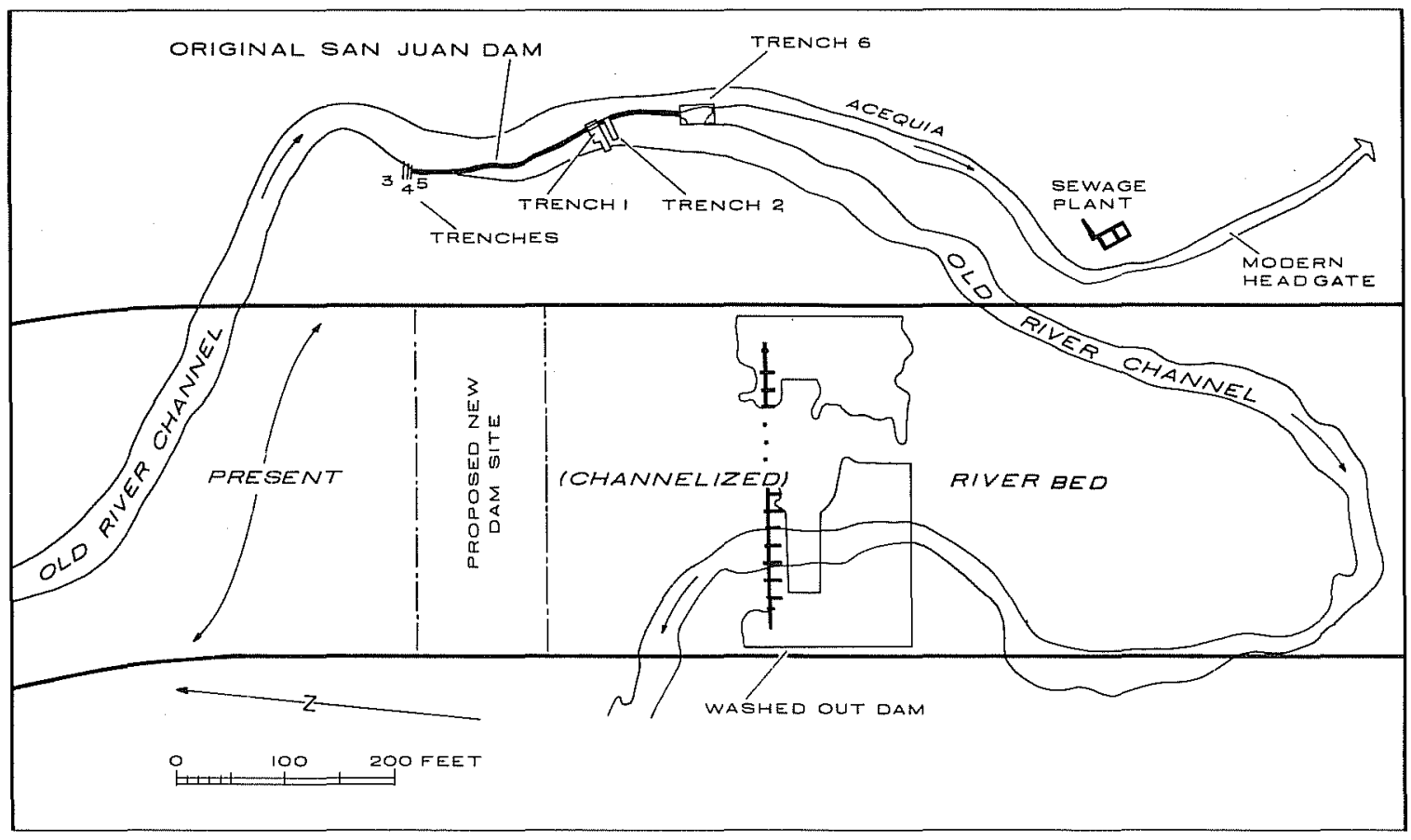

Figure 1. Location of the San Juan Dam and Trenches 1-6. 
1730, it was moved to the Colorado River near present-day Austin, and the following year was reestablished on the San Antonio River about seven miles south of downtown San Antonio. Because of its proximity to Mission San José y San Miguel de Aguayo, the mission was renamed San Juan Capistrano. By May 4, 1731, the first temporary structures had been completed (Habig 1968:169). It is highly likely that the acequia, or irrigation ditch, was also begun at that time, as this was the normal procedure of the Spanish. The ability to develop an irrigation system was a primary factor in selecting a site for any mission.

Despite the importance of the acequias, thure is little recorded detail on the construction of these vital waterways. One exception is the report of Fray Mariano on the establishment of the missions on the San Xavier River (now the San Gabriel River) as evidenced by the following account:

He proceeded to order the ministers to be prepared to assist in the work on the fifteenth (October, 1750), each mission provided as many yokes of oxen as it might have, seven bars, fifteen picks, four axes, and one cauldron. In excess of the regular rations, which would be continued, each mission was asked to provide each week during the continuance of the work, a tierce [(sic) this should read tercio, one third] or half a mule load of salt, six bulls for slaughter, two handfuls of tobacco, and whatever else was possible. Fray Mariano promised to provide for distribution each day a fanega [generally accepted to be a hundred weight or 1.60 bushels], or two hundred pounds of hominy (Bolton 1915:235).

Even with the encouragement of these extra rations to coax the Indians to work, Fray Mariano also instructed the military to send "enough soldiers to cause respect" (ibid.:236).

Progress on the construction of Mission San Juan Capistrano, and probably its acequia, was slow during the first ten years due to frequent Apache raids, the obstructionist tactics of Governor Franquis de Lugo, and an epidemic in 1739 (Habig 1968:162). However, the acequia was in operation by at least 1740 , for the fields are reported as newly planted in the spring of that year (ibid::167). In 1745, the report of Fray Francisco Xavier Ortiz stated:

The mission farm was watered by a very good irrigation ditch. As a rule $62 / 5$ bushels of seed corn were planted each year, and in good years they yield 1,280 . About 2 2/5 bushels of beans produced about 64 bushels ... (Habig 1968:167).

The dam that serviced the San Juan acequia was not a water barrier as in the conventional manner, but rather a diverting device to direct the water into the acequia toward the headgate some distance from the channel. The lengthy structure was constructed along the west bank of the river jutting out into the stream to direct the flow toward the ditch. At normal water levels the proper amount of water filled the acequia, but at higher levels the flow was allowed to spill over the dam and return to its original channel (Fig. 1).

In April 1749, San Juan Capistrano was partially secularized. Portions of the mission lands were set aside as communal farms, and small plots were distributed to the 12 heads of families of the mission Indians. San Juan Capistrano then came under the jurisdiction of the priest of Mission San Francisco de la Espada. The mission operation continued on a small scale until full secularization occurred in 1824 (Habig 1968:180).

The acequia continued to be used to irrigate the 486 acres of mission lands that were then owned by individuals. In 1889, the State of Texas enacted legislation to "encourage irrigation and provide for the construction and maintenance of canals, ditches, flumes, reservoirs and wells for irrigation, and for mining, milling, and stock raising in the arid districts of Texas" ( $B C A$ Water Rights Book of Records 1880-1900:5). At the time of the legislation the San Juan ditch had been abandoned but was still in a good state of preservation (Everett 1975:13).

In 1900, a corporation, the San Juan Ditch Company, was established to maintain and administer the system. The persons entitled to use water from the ditch transferred their water rights to the company in return for shares. The first president of the company was Celestine Villemain (SACS 1977:11). He had 300 acres in cultivation, five acres of which were in grapes from which he produced wine (Everett 1975:17). In April 1914, 
the company was rechartered with Milton Meier as president and P. J. Pfeiffer as secretary and treasurer. Their charter stated that the dam diverted 21 cubic feet of water per second into the ditch to water the "San Juan Mission Fields." The fields are described as "Beginning at the intake or head-gate of the San Juan Ditch on the San Antonio River ... thence in a southerly direction along said San Juan Ditch to the San Antonio River thence up said river to the place of beginning" ( $B C A$ Water Rights Book of Records 18801900:196-203).

In the 1950s, the Corps of Engineers and SARA, the local sponsor, in their efforts to maintain flood control, straightened and widened the river channel diverting the flow away from the San Juan dam and its headgate, thus terminating irrigation. This resulted in lawsuits and countersuits between the SARA and the landowners. After several court decisions, the case was settled in favor of the landowners. The SARA agreed to restore the operation of the dam and provided gravity diversion of water to the ditch (SACS 1977:6). The dam was destroyed by a flood in September 1977. The SARA installed a pumping system to divert water into the acequia, but because the acequia had been filled in places or washed out, the pumps are temporarily off until repairs are made by the owners or the National Park Service.

\section{ARCHAEOLOGICAL BACKGROUND}

No archaeological excavations have been done in the area of the San Juan dam, and limited archaeological research has been done concerning the location and construction of the San Juan dam. In 1978, Fred Valdez of the Center staff conducted test excavations just north of the current investigations (Valdez 1978). Before 1976, archaeologists from the Texas Historical Commission conducted research on the location and history of the dam for the Mission Parkway project, but no archaeological excavations were done at that time (Scurlock et al. 1976).

\section{ARCHAEOLOGICAL INVESTIGATIONS}

The archaeological investigations of the San Juan dam site had three objectives: (1) to deter- mine the location and physical boundaries of the dam; (2) to investigate the construction methods used in building the dam; and (3) to determine the location of the original San Juan acequia and its headgate. All field notes, photographs, and drawings pertaining to this project are on file at the CAR-UTSA.

First, the exact location of the dam needed to be determined. With the help of SARA personnel, who had previously located parts of the dam, the top of the dam was quickly exposed with a backhoe. The structure has a north-south orientation, extending approximately 300 feet along the west side of a section of the old river channel (Fig. 1). This section of the old channel is situated to the east of the existing rechanneled river. The dam appears to be about three feet thick and three feet high at the center. This translates into approximately one vara by one vara in Spanish measurements. These measurements seem to be rather consistent along the length of the dam except for the southern or trailing end, which flares out to a greater dimension.

With the location and extent of the dam structure confirmed, six test trenches were excavated to investigate the subsurface construction methods and original materials. Three areas of the dam were exposed by trenching: the northern (leading) end, the midsection, and the southern (trailing) end. The soil color evaluations are rated according to the Munsell Soil Color Charts (1975).

The first area exposed was the midsection of the dam. Trench 1 was located perpendicular to the dam structure and extended across the dam, exposing both sides of the structure. The upstream (eastern) face appears to be composed of river gravel and a caliche and lime mortar forming an early type of concrete. The top of the dam in this area has been capped with a modern cement (Fig. 2,a). Below (underneath) the modern cement cap the original dam can be seen. The western portion of this trench exposed the downstream (western) surface of the dam. With this portion cleared, it is possible to see that the modern concrete cap extends only six to eight inches below the top of the dam.

The top of the dam currently lies two to four inches below the ground surface in Trench 1 (Fig. 3). At this point, below the ground surface, there is a distinct soil change. Above this point is a very dark gray brown clay (2.5Y 3/2) with large gravel. This soil deposit (A) is associated with the 


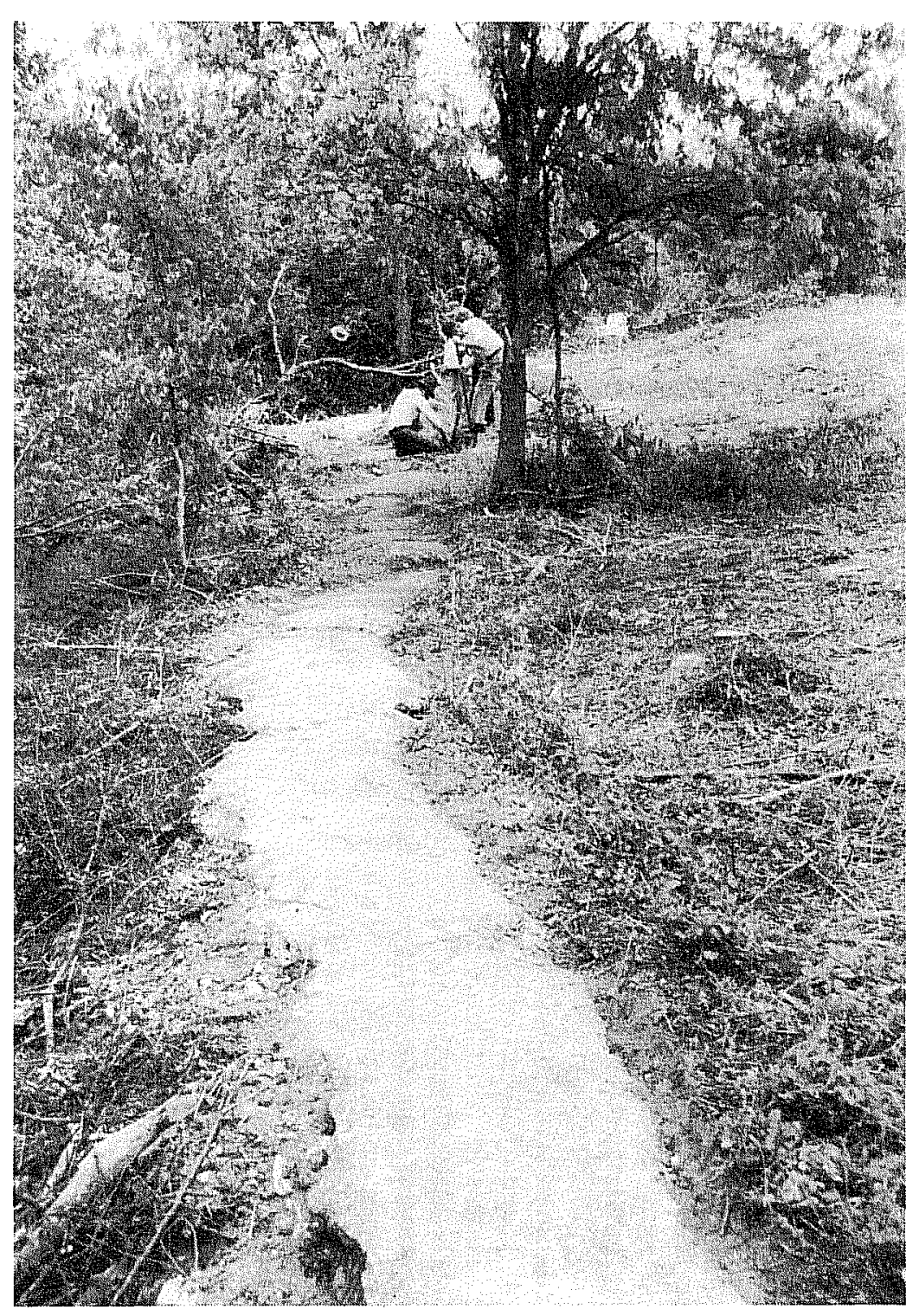

a

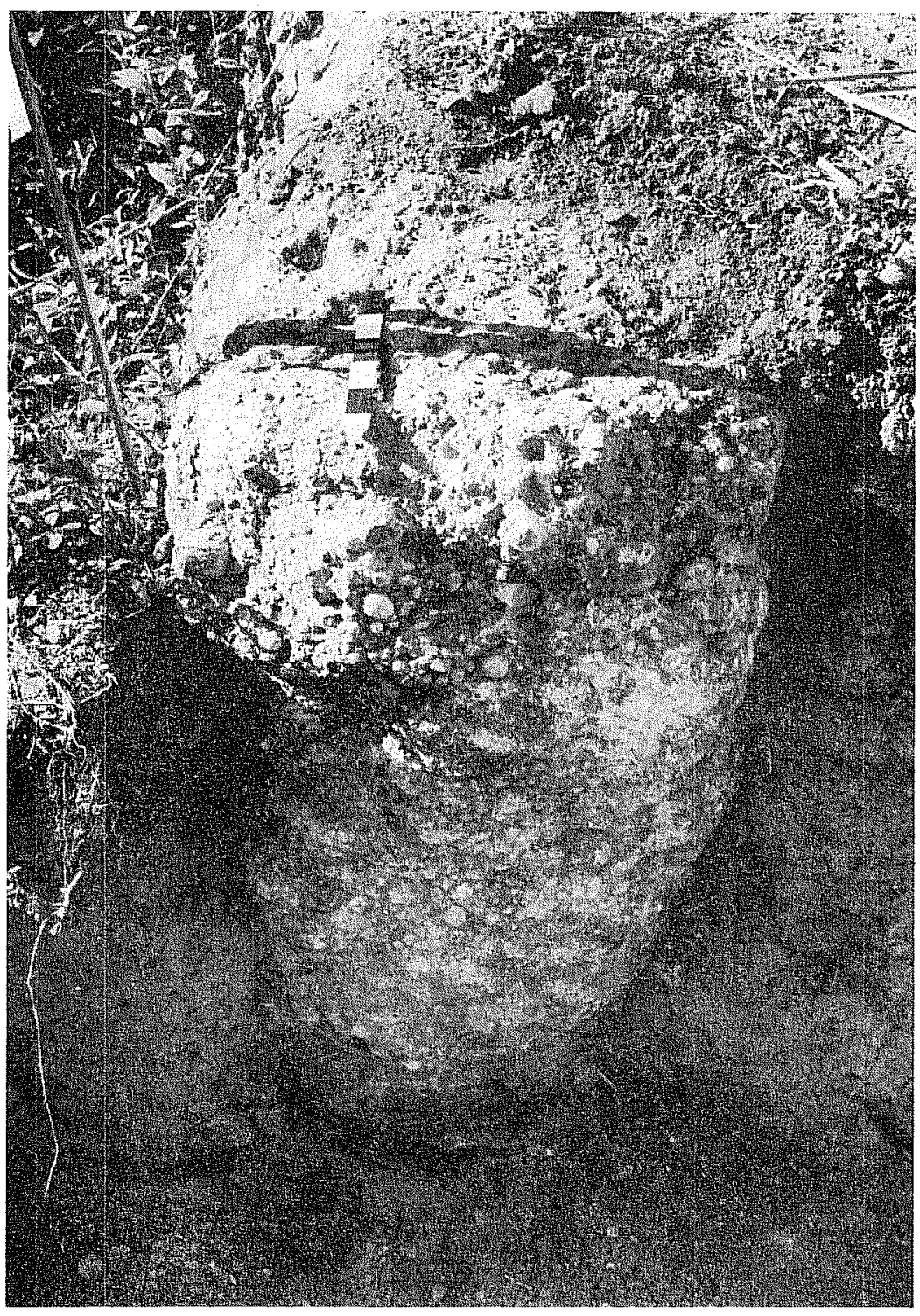

b

Figure 2. Views of Excavations. a, cement cap on dam looking south; b, end view of dam (Trench 5) showing construction. 


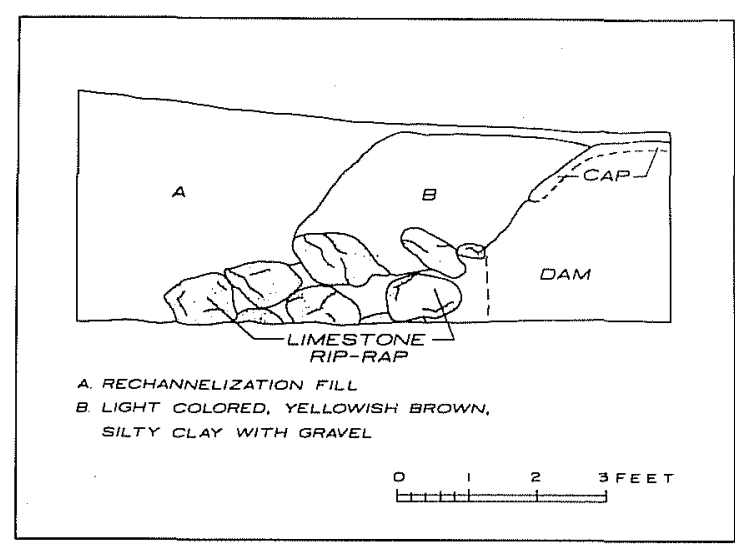

Figure 3. Trench 1, South Wall Profile.

rechanneling of the river that took place in the late $1950 \mathrm{~s}$. When the river was rechanneled and widened, the dirt that was removed was used to fill and raise this area. This deposit contained debris such as a plastic cigarette lighter, clear glass, screw top bottle fragments, shoe leather, and bricks. These are all artifacts that could have been deposited during the dredging of the river.

The soil layer (B) beneath is a light colored, yellowish brown silty clay (2.5Y 6/4) with some gravel. This layer appears to be associated with the overrun of the dam. Soil was carried downstream by the river and deposited in front of the dam. This soil continued to be deposited year after year causing this layer to be built up. Some of the artifacts found in this layer were ceramic sewer tile, fragments of a composition battery case, and clear glass.

A small lens (C) of a very compact, dark gray clay (10YR 3/1) was encountered next. Since there were no artifacts recovered from this deposit, and it did not appear to continue either north or south along the dam, it is difficult to be certain of the exact origin of this lens; however, it did appear to be sedimentary. It is possible that this lens is also associated with an earlier period of overrun of the dam. The lens is above a layer of large limestone boulders. The stones do not seem to be shaped and appear to be random in their placement, and also appear to be associated with the original construction of the dam. They form a foundation and rear rip-rap formation. These stones would have helped support the dam structure against the rushing water.

The second trench was located approximately $1 \mathrm{~m}$ south of the first. This trench exposed only the downstream (western) face of the dam (Fig.4). The dam structure and soil deposition here appear to be very similar to that in the first trench. The first two soil layers (A and B) are still present in this trench in very much the same configuration as in Trench 1. The third soil layer (C) in the first trench, however, does not seem to have continued this far south along the dam. Trench 2 does, however, provide a much better view of the limestone rip-rap support than does Trench 1. The modern concrete cap can also be clearly noted in this trench. Similar artifacts as noted in the first two layers of Trench 1 were also present in the corresponding layers of Trench 2 .

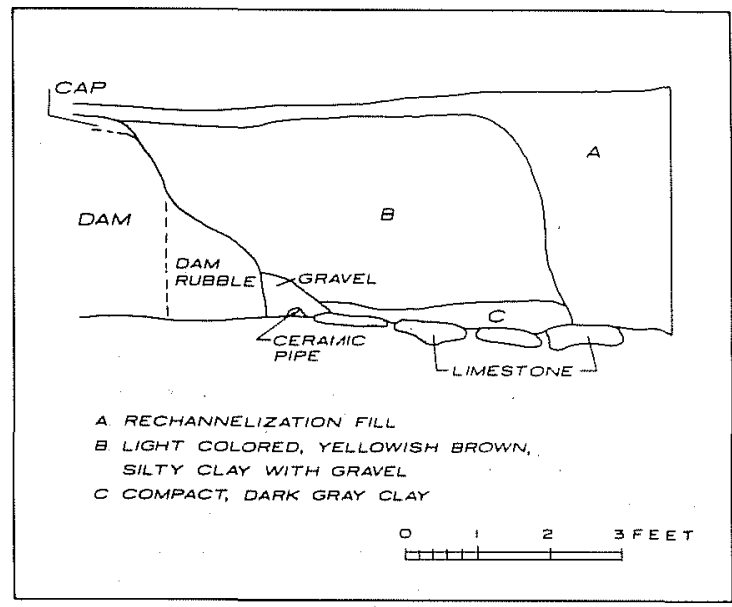

Figure 4. Trench 2, North Wall Profile.

The third and fourth trenches were positioned to test for the northern end of the original dam structure. These trenches were placed in the approximate location of the northern end of the dam, about $1.5 \mathrm{~m}$ apart. The trenches extended approximately $4 \mathrm{~m}$ in an east-west orientation and were about $1 \mathrm{~m}$ wide by $1.5 \mathrm{~m}$ deep. No evidence of the dam or any other subsurface disturbance indicating previous construction was noted in either of these trenches. Once observations of these trenches were made, they were backfilled.

Trench 5 was located about $1 \mathrm{~m}$ to the south of Trench 4 and exposed the northern end of the original dam structure in its southern profile (Fig. $2, \mathrm{~b})$. The soil deposits in this trench seem to differ somewhat from those of the first two trenches (Fig. 5). The first layer (A) in Trench 5 seems to be a continuation of the fill associated with the rechannelization of the river. 


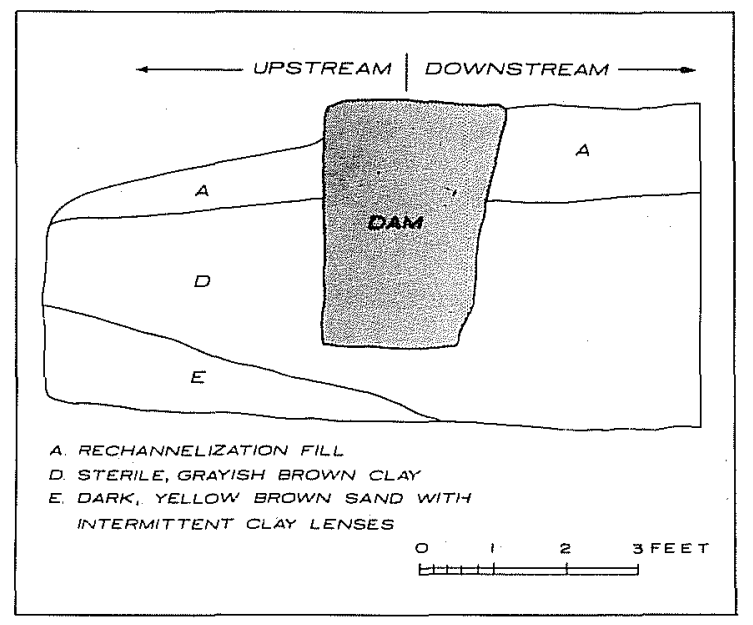

Figure 5. Trench 5, South Wall Profile.

Below this fill layer, however, is a thick layer (D) of sterile, grayish brown clay (10YR5/2). Since this clay is present on both sides of the dam and appears to be in situ, it is possible that when the dam was originally constructed it was cut down into this clay to provide additional support to the leading end of the dam. Below this thick layer (D) is dark, yellow brown sand (10YR 4/6) with several intermittent lenses of clay (E). This layer (E) is thought to represent the original riverbed in the channel. The intermittent lenses of sand and clay in this layer represent the periods of meandering and silting common to this part of the river. No artifacts were recovered from any of the layers in this trench, giving further support to the idea that layers $D$ and $E$ are intact soil deposits.

The original construction of the dam can be seen clearly from this trench. The front (upstream) side of the dam appears to have been straight, while the back (downstream) side seems to have sloped back from top to bottom. The material used in construction seems to have been the same as previously noted - a caliche and lime mortar with gravel forming an early type of concrete. The modern concrete cap visible in the first two trenches is not present in this profile.

Trench 6 was located approximately $20 \mathrm{~m}$ to the south of Trench 2 and exposed the southern end of the dam. This end of the dam varies a great deal more in its construction than the other areas previously exposed (Fig. 6). This section flared out to a much wider dimension than the rest of the dam. Partially exposed, it appeared that the end of the dam branched off in a westerly direction.
Modern support and reinforcement are obvious in this section of the dam. Along the eastern edge, a concrete boulder rip-rap is visible. Several of the concrete boulders still have imprints of the burlap bags in which they were formed. On the southern edge is a portion of a concrete slab with metal strapping and wire mesh reinforcement. The modern concrete cap that was noted in the first two trenches can be followed along the ground surface to the northern end of this area. All of the soil that overlies this end of the dam seems to resemble the fill associated with the rechannelization of the river.

An archival search of the San Juan Ditch Company records revealed a probable location of the headgate as it existed during the late $1800 \mathrm{~s}$ ( $B C A$ Water Rights Book of Records 1880-1900:196). The area was located, and an intensive search and limited shovel testing were conducted both in the channel and the upper terrace, but no evidence of the headgate could be detected.

\section{DISCUSSION AND CONCLUSIONS}

It is difficult to trace the exact route of the old river channel from where the acequia branched off. The topography of the area has been drastically modified by the rechanneling of the river in the late 1950s and the landscaping that was undertaken in 1966 for the construction of a park.

As it turns out, the area first thought to be part of the old river channel is actually the original route of the acequia. Heading southwest, from the dam structure, the river took a route to the south of the dam. The existing ditch to the southeast of the dam is actually the acequia. The dam structure was used to divert water from the San Antonio River into the acequia. Only when the water in the river was over the height of the dam was water put back into the river channel (Fig. 7,a). All of the water that was lower than the top of the dam was directed into the acequia (Fig. $7, \mathrm{~b})$.

There are reports that the headgate to the acequia was a large, stone structure located 150 feet south of the dam (BCA Water Rights Book of Records 1880-1900:196-203). However, no visible evidence remains that might help substantiate these reports. It is possible that the original headgate was destroyed by one of two large floods that occurred along the San Antonio River during 


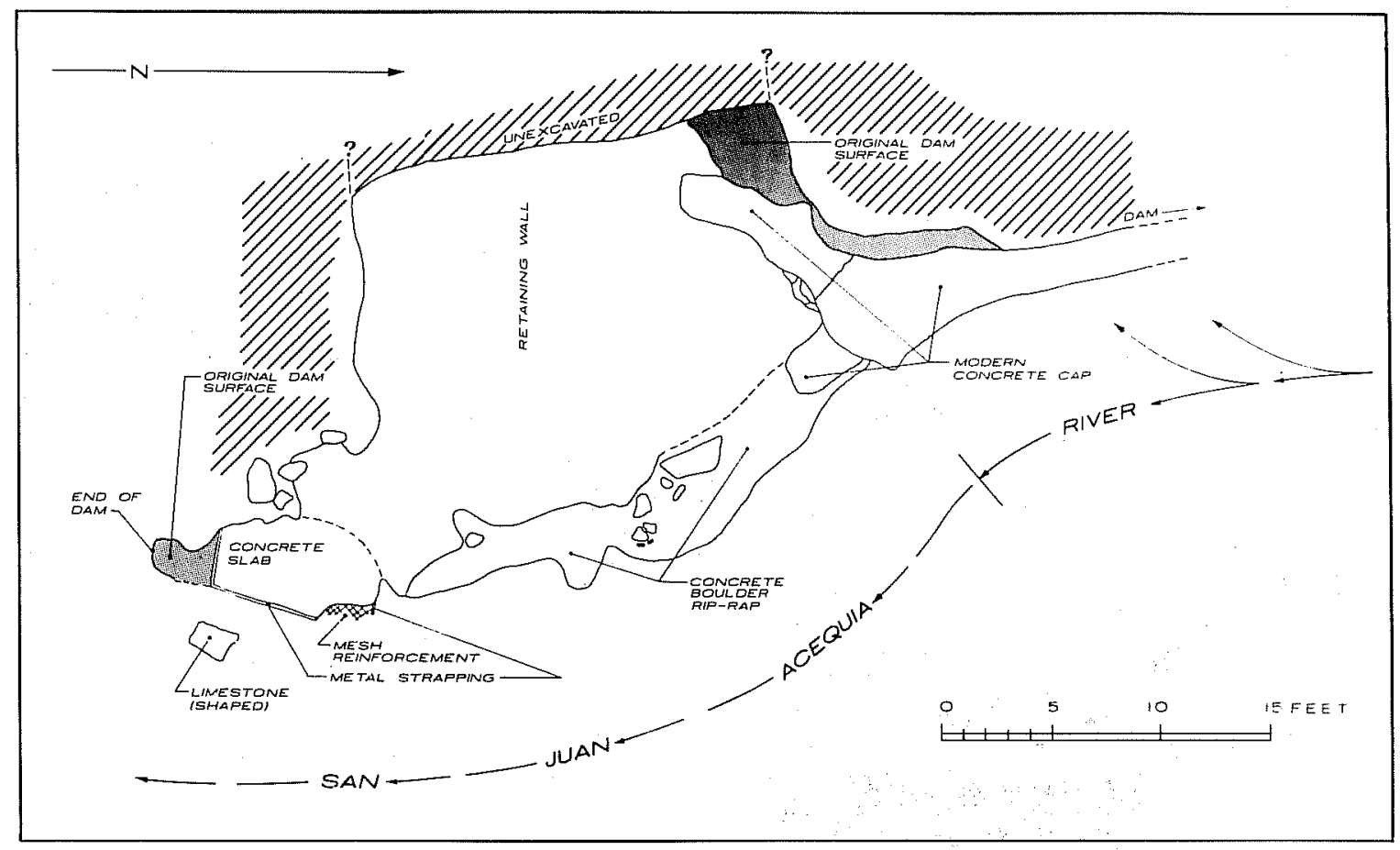

Figure 6. Plan of Trench 6.

the 1920s. Located some 400 feet downstream from the dam in the acequia is a modern concrete, stone, and metal gate. It was first thought that this modern gate (constructed when the river was rechannelized [Walter Stewart, personal communication]) might have been placed in the same location as the original, but no evidence supports the original headgate being located this far downstream from the dam.

The modern concrete cap that is present in Trenches 1,2, and 6 appears to have been put on in an effort to preserve the original dam structure and prevent any additional deterioration. This modern work may have been done in conjunction with the improvements made in 1966 when the area became part of a park.

The large formation partially exposed by Trench 6 appears to have been used as a retaining wall. This part of the structure was designed to make sure that all of the water coming over the dam was forced back into the river channel. It prevented the area between the acequia and the river channel from becoming a swamp. This also prevented the water from running around the south end and undercutting the dam, and kept the acequia and river from joining together below the dam.
All of the previous work done in this area states that the structure that we investigated is a dam. The term "dam" is not only misleading, but technically incorrect. The word dam is defined as:
A bank or barrier of earth, masonry, etc., constructed across a stream to obstruct its flow and raise its level, so as to make it available for turning a mill-wheel or for other purposes; a similar work constructed to confine water so as to form a pond or reservoir, or to protect the land from being flooded (Oxford English Dictionary 1981).

The structure constructed at the beginning of the San Juan acequia was never intended to obstruct the flow of the river, or cause a pond and reservoir to be formed. More correctly, this structure was intended only to divert or direct the flow of the river into the acequia. Therefore, the word dam is not correct. Since the structure does not span the width of the river and it is not constructed to pool water, a weir is the more accurate description of the structure's form and function. The term "weir" is defined as: 


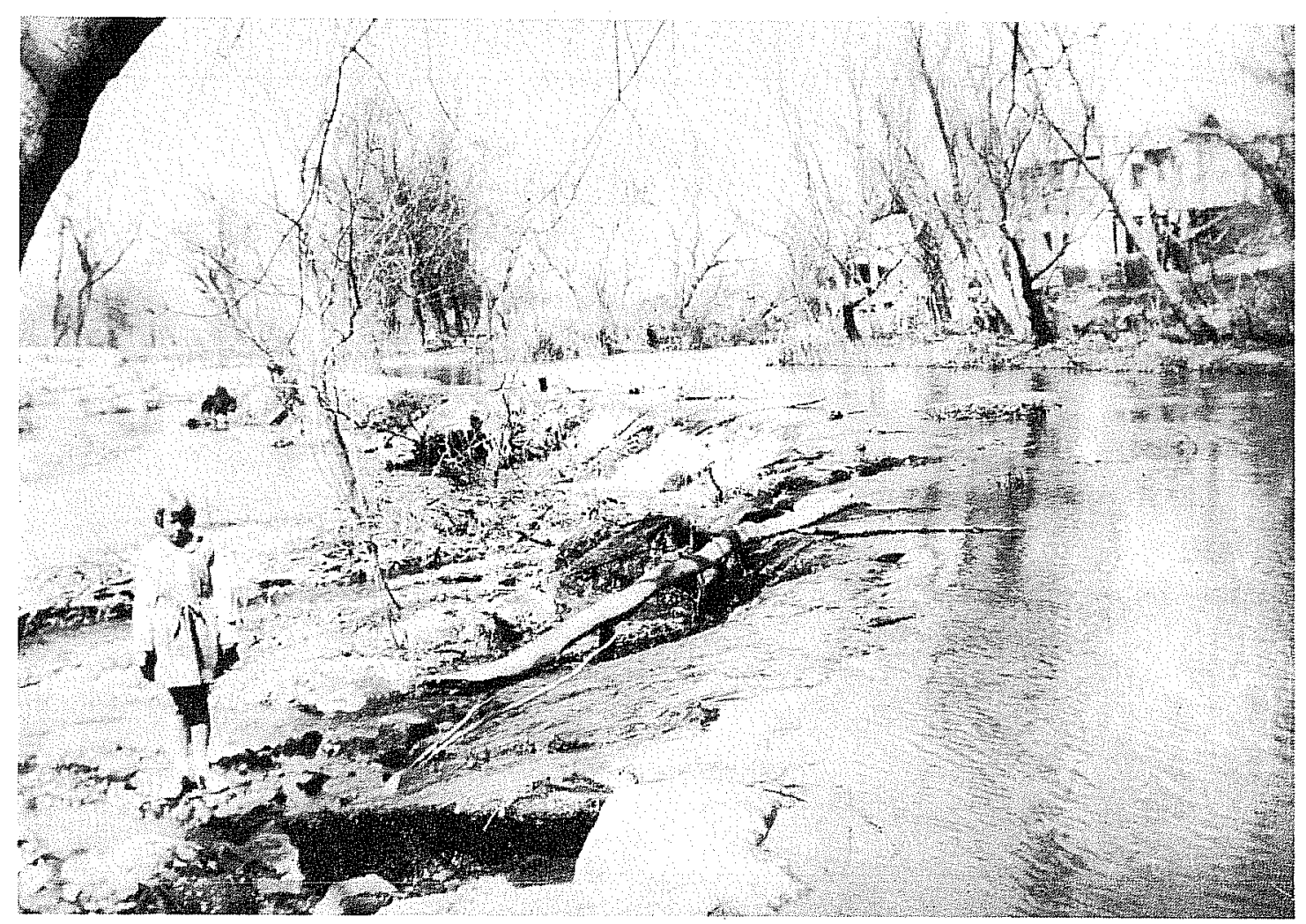

a

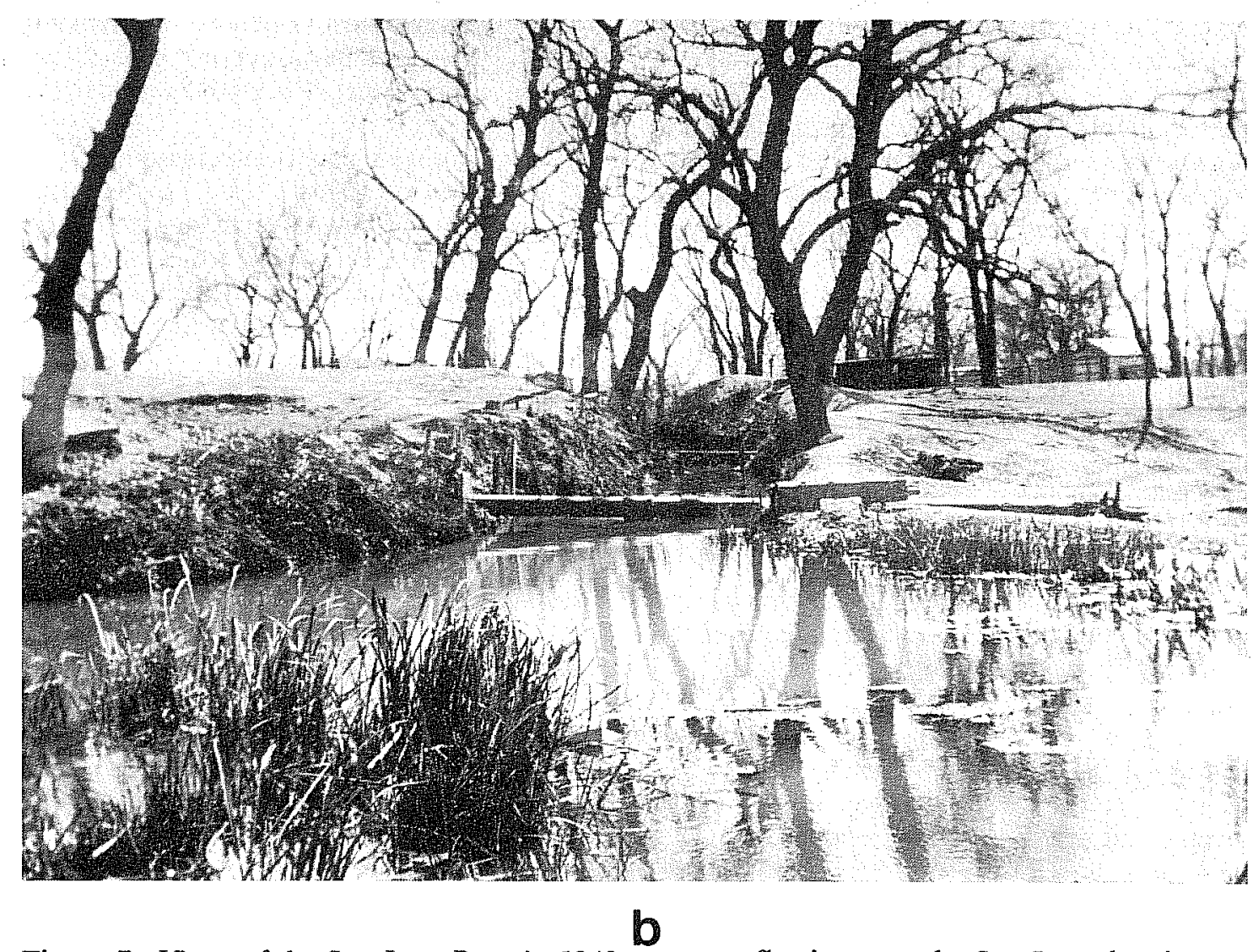

Figure 7. Views of the San Juan Dam in 1940. a, water flowing over the San Juan dam in 1940, looking north; b, looking south into the acequia from the same location, 1940. Photographs taken from the Schuchard collection at the Daughters of the Republic of Texas Research Library, The Alamo. 
A fence or embankment to prevent the encroachment of a river or sea-sand, or to turn the course of a stream (Oxford English Dictionary 1981).

\section{RECOMMENDATIONS}

As a result of the excavations, we now have a better understanding of the construction and purpose of the San Juan dam. In order to obtain any additional information, we recommend that a qualified archaeologist monitor any work in or around the area of the dam.

Although not specifically listed as a property on the National Register, the San Juan dam is protected as a portion of the National Register Mission Parkway Historical/Archaeological District. It is recommended that the San Juan dam be nominated for State Archeological Landmark status.

\section{REFERENCES CITED}

\section{Bexar County, Texas \\ Bexar County Archives (BCA)}

1880- Water Rights Book of Records, Bexar

1890 County Courthouse, San Antonio, Texas.

Bolton, $\mathrm{H}$.

1915 Texas in the Middle Eighteenth Century. University of Texas Press, Austin.

Everett, D. E.

1975 San Antonio, The Flavor of its Past, 1845-1898. Trinity University Press, San Antonio.

Habig, Fr. M. A.

1968 The Alamo Chain of Missions, A History of San Antonio's Five Old Missions. Franciscan Herald Press, Chicago, Illinois.

\section{Munsell Soil Color Charts}

1975 Macbeth Division of Kollmorgen Corporation, Baltimore, Maryland.
Oxford English Dictionary

1981 Oxford University Press, London.

San Antonio Conservation Society (SACS)

1977 Newsletter. September-October. San Antonio.

Scurlock, D., A. Benavides, Jr., D. Isham, and J. W. Clark, Jr.

1976 An Archeological and Historical Survey of the Proposed Mission Parkway, San Antonio, Texas. Office of the State Archeologist, Texas Historical Commission, Archeological Survey Report 17, Austin.

Valdez, F., Jr.

1978 Archaeological Investigations at the San Juan Damsite (41 BX 266). Letter report on file at the Center for Archaeological Research, The University of Texas at San Antonio.

Webb, W. P., editor

1952 Handbook of Texas. Two volumes. The Texas State Historical Association, Austin. 


